\title{
Biotechnological Potential of Agro-Industrial Wastes as a Carbon Source to Thermostable Polygalacturonase Production in Aspergillus niveus
}

\author{
Alexandre Maller, ${ }^{1}$ André Ricardo Lima Damásio, ${ }^{1}$ Tony Marcio da Silva, ${ }^{2}$ João Atílio Jorge, ${ }^{2}$ \\ Héctor Francisco Terenzi, ${ }^{2}$ and Maria de Lourdes Teixeira de Moraes Polizeli ${ }^{2}$ \\ ${ }^{1}$ Biochemistry and Immunology Department, Ribeirão Preto School of Medicine, São Paulo University, Avenue Bandeirantes, \\ 3900, 14049-900 Ribeirão Preto, SP, Brazil \\ ${ }^{2}$ Biology Department, Philosophy, Ribeirão Preto School of Philosophy, Sciences and Literature, São Paulo University, \\ Avenue Bandeirantes, 3900, 14040-901 Ribeirão Preto, SP, Brazil \\ Correspondence should be addressed to Maria de Lourdes Teixeira de Moraes Polizeli, polizeli@ffclrp.usp.br
}

Received 27 October 2010; Revised 15 March 2011; Accepted 23 April 2011

Academic Editor: Richard John Ward

Copyright (C) 2011 Alexandre Maller et al. This is an open access article distributed under the Creative Commons Attribution License, which permits unrestricted use, distribution, and reproduction in any medium, provided the original work is properly cited.

Agro-industrial wastes are mainly composed of complex polysaccharides that might serve as nutrients for microbial growth and production of enzymes. The aim of this work was to study polygalacturonase (PG) production by Aspergillus niveus cultured on liquid or solid media supplemented with agro-industrial wastes. Submerged fermentation (SbmF) was tested using Czapeck media supplemented with 28 different carbon sources. Among these, orange peel was the best PG inducer. On the other hand, for solid state fermentation (SSF), lemon peel was the best inducer. By comparing SbmF with SSF, both supplemented with lemon peel, it was observed that PG levels were 4.4-fold higher under SSF. Maximum PG activity was observed at $55^{\circ} \mathrm{C}$ and $\mathrm{pH} 4.0$. The enzyme was stable at $60^{\circ} \mathrm{C}$ for $90 \mathrm{~min}$ and at $\mathrm{pH} 3.0-5.0$. The properties of this enzyme, produced on inexpensive fermentation substrates, were interesting and suggested several biotechnological applications.

\section{Introduction}

Pectolytic enzymes are involved in the degradation of pectin, a structural component of the middle lamella and the primary cell walls of plants. Pectins are complex colloidal acidic polysaccharides that show a backbone of galacturonic acid residues with $\alpha$-1,4-glycosidic linkages [1]. These molecules possess L-rhamnose, arabinose, galactose, and xylose in the side chains. Also, the carboxylic groups in the galacturonic acid chain are neutralized by different ions, as $\mathrm{Na}^{+}, \mathrm{K}^{+}$, and $\mathrm{NH}_{4}{ }^{+}$[2]. Pectins comprise a family of oligosaccharides and polysaccharides that have common features, but are extremely diverse in their fine structures. However, all pectins are rich in galacturonic acid (GalA) and they have at least 65\% GalA.

Pectinolytic enzymes break down pectin or pectate by the hydrolysis of $\alpha$-1,4-glycosidic linkages and they have varied biotechnological applications. The acidophilic pectinases have extensive applications in the manufacture of fruit juices and wine. They are used in apple juice preparation and clarification, to facilitate pressing and juice extraction. Moreover, pectic enzymes are used to reduce haze or gelling of grape juice in wine manufacture and to enhance the quality of cider apple varieties that are bitter, sweet, or sour [3,4]. The alkaline pectinase also has various industrial applications, such as wastewater treatment, paper manufacturing, oil extraction, coffee and tea fermentation, processing and degumming of many plant fibers [3].

Several fungal species are effective degraders of pectic substances, being able to produce high amounts of pectinolytic enzymes [1]. A novel strain of A. niveus was isolated from Brazilian soil, which produces high levels of several hydrolytic enzymes, such as xylanase $[5,6]$ and amylases $[7,8]$. In this work, we demonstrated that this fungus also produced high polygalacturonase levels when grown on 
TABLE 1: Effect of liquid media on growth and PG activity of A. niveus.

\begin{tabular}{lcc}
\hline Media & $\begin{array}{c}\text { Relative growth } \\
(\%)\end{array}$ & $\begin{array}{c}\text { Relative activity } \\
(\%)\end{array}$ \\
\hline M-5 & $24 \pm 0.4$ & $32 \pm 0.8$ \\
Adams & $100 \pm 0.3$ & $62 \pm 0.4$ \\
Khanna & $6 \pm 0.1$ & $18 \pm 1.7$ \\
SR & $27 \pm 0.4$ & $33 \pm 1.3$ \\
Czapeck & $34 \pm 0.4$ & $100 \pm 1.7$ \\
\hline
\end{tabular}

A. niveus was grown in $1 \%$ citric pectin media, for 3 days at $40^{\circ} \mathrm{C}$.

agricultural wastes, such as orange peel and passion fruit peel. This work leads to future biotechnological applications, and it also contributes to diminish the environmental pollution consequent of the accumulation of citric residues that are discarded in the environment.

\section{Materials and Methods}

2.1. Organism and Growth Conditions. Aspergillus niveus was isolated from Mangifera indica in our laboratory. The microorganism was identified and deposited in the culture collection of Pernambuco Federal University (PE, Brazil). The organism was maintained on slants of potato dextrose agar (PDA) medium covered with mineral oil, at $4^{\circ} \mathrm{C}$. The fungus was incubated on PDA medium, at $30^{\circ} \mathrm{C}$ for 15 days previous to the cultivation and optimization experiments. After that, $5 \times 10^{6}$ conidia from these cultures were inoculated into $125-\mathrm{mL}$ Erlenmeyer flasks containing $25 \mathrm{~mL}$ of liquid Czapeck medium [9] with $1.0 \%$ citric pectin Sigma (w/v) or other carbon sources as described in Results. The cultures were incubated at $40^{\circ} \mathrm{C}$, under agitation $(100 \mathrm{rpm})$ or under static conditions, for different periods, depending on the experiment. Other media were used to standardize the pectinolytic production, such as M-5 [10], Adams [11], Khanna [12], SR-Segato Rizzatti et al. [13] and Czapeck medium [9]. Cultures were filtered through Whatman no. 1 in a Buchner funnel. The filtrate was saved as a source of crude extracellular polygalacturonase. Micelial pads were ground with sea sand, at $4^{\circ} \mathrm{C}$ with ten vol. of cold $100 \mathrm{mM}$ sodium acetate buffer, $\mathrm{pH}$ 6.0. After centrifugation $\left(15,000 \mathrm{xg}, 15 \mathrm{~min}, 4^{\circ} \mathrm{C}\right)$, the supernatant fraction was the source of crude intracellular enzyme.

2.2. Culture Condition under SSF. The fungus was inoculated $\left(5 \times 10^{6}\right.$ conidia $\left./ \mathrm{mL}\right)$ on SSF medium, composed by $2 \mathrm{~g}$ of different agro-industrial residues plus $4 \mathrm{~mL}$ of sterile distilled water. After the incubation period, the cultures were added of $50 \mathrm{~mL}$ of distilled water, maintained on ice and agitated for $30 \mathrm{~min}$, after that, the extract fluid was separated from the solid residues as described in Section 2.1, and the filtrate was the source of crude extracellular polygalacturonase.

2.3. Enzymatic Assays and Protein Determination. Polygalacturonase activity was assayed according to Miller [14].
The enzymatic assays were carried out with $50 \mu \mathrm{L}$ of enzyme and $1.0 \%$ polygalacturonic acid sodium salt from SigmaAldrich in $100 \mathrm{mM}$ acetate buffer $\mathrm{pH} 4.0$, as substrate. The reactions occurred at $60^{\circ} \mathrm{C}$, for $5 \mathrm{~min}$. A unit was defined as the amount of enzyme that releases $1 \mu \mathrm{mol}$ of reducing sugar per min under the assay conditions. Protein was assayed according to Lowry et al. [15], using bovine serum albumin as the standard. Total activity and total protein represent $\mathrm{U} / \mathrm{mL}$ or $\mathrm{mg} / \mathrm{mL}$ multiplied by total volume of culture filtrate.

2.4. Reproducibility of the Results. All data are the mean of at least three independent experiments showing consistent results.

\section{Results}

3.1. Time-Course of Polygalacturonase Production. Regarding the nutritional composition of the culture medium, an experiment was carried out according to Cereia et al. [16]. A. niveus was preliminarily grown on a variety of liquid media (Table 1). Among them, Czapeck medium was the best inducer for the PG production.

Then, the time-course of PG production was followed only with Czapeck medium added of $1 \%$ citrus pectin SigmaAldrich $(\mathrm{w} / \mathrm{v})$. The incubation occurred without agitation, up to 9 days, at $40^{\circ} \mathrm{C}$, or under agitation for up to 5 days, at $40^{\circ} \mathrm{C}$. Maximum growth occurred after four days without agitation (Figure $1(\mathrm{a})$ ) and the PG production occurred after five days (Figure 1(b)).

3.2. Effect of Carbon Sources on Growth and Enzymatic Production on SbmF and SSF. The effect of the carbon sources on SbmF was studied by supplementing the Czapeck medium with 28 carbohydrates and/or agro-industrial wastes (Table 2). The cultures were incubated under agitation for 5 days and the fungal growth was expressed as total protein. The best source for PG production activity was orange peel, which was 21 -fold higher than the basal activity in medium supplemented by glucose. Another agro-industrial residue tested was passion fruit peel, which resulted in PG levels 19-fold higher than the one in glucose-medium. Furthermore, lemon peel, apple peel, gum guar, commercial mate herb (Illex paraguariensis), and corncob were also tested and contributed to produce high PG activity from A. niveus. Sigma-Aldrich, CPKelco 8003, and Vetec citrus pectins led to about 19 -fold increase in PG activity in relation to that attained on glucose-containing media. Pectins from different origins induced lower PG levels as well as polypectate acid salt sodium and monogalacturonic acid that were poor inducers.

Polygalacturonase production on SSF was studied by incubating the fungus with 8 different agro-industrial residues (Table 3) for 7 days. Under this condition, lemon peel was the best inducer of PG activity. Besides, passion fruit peel was an interesting inducer showing the second best level. The other residues tested showed about half of the activity of the carbon sources previously mentioned. 


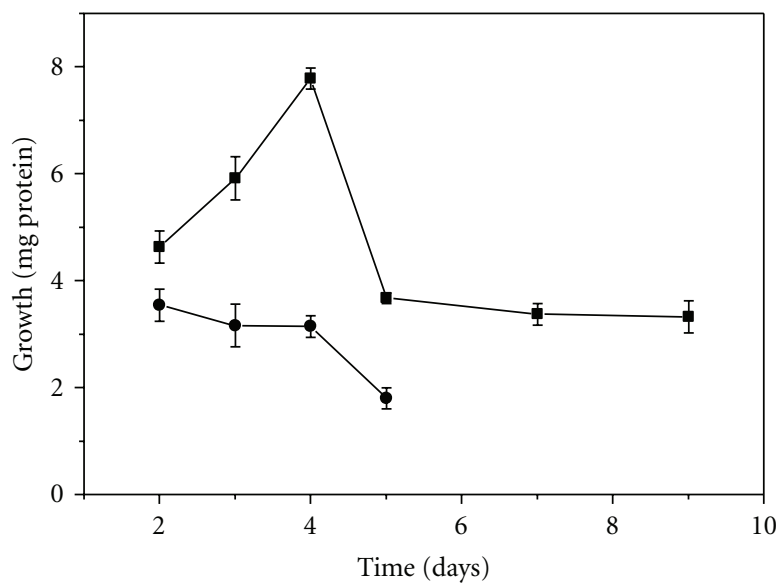

(a)

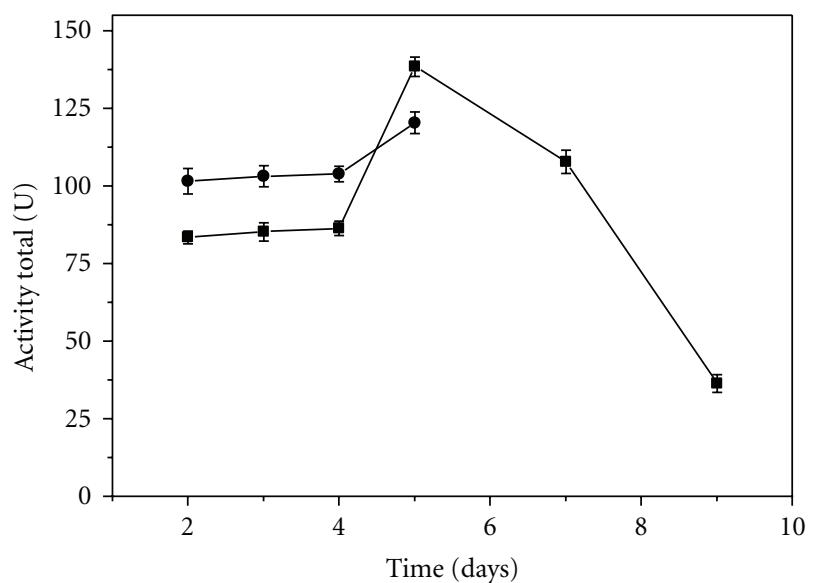

(b)

Figure 1: Time course of $A$. niveus cultivation. (a) Growth, (b) PG production, ( $\square$ ) static condition, (•) agitation condition.

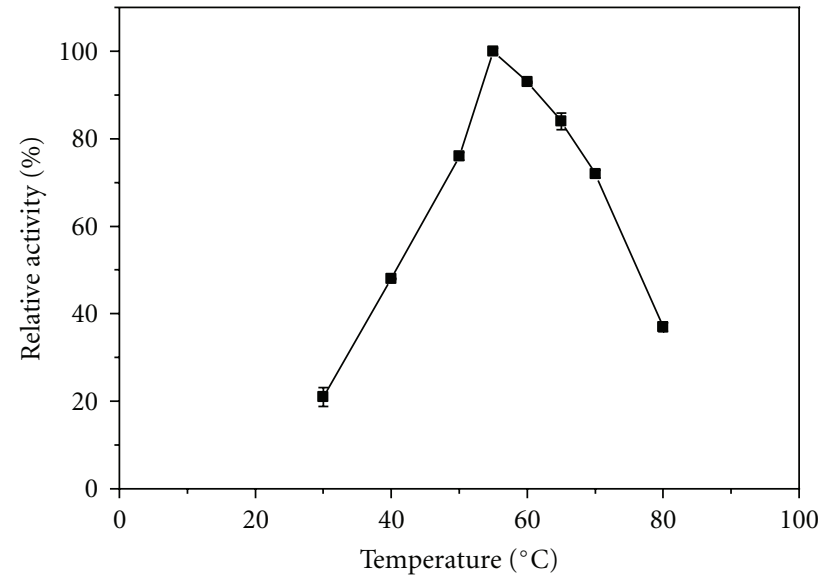

(a)

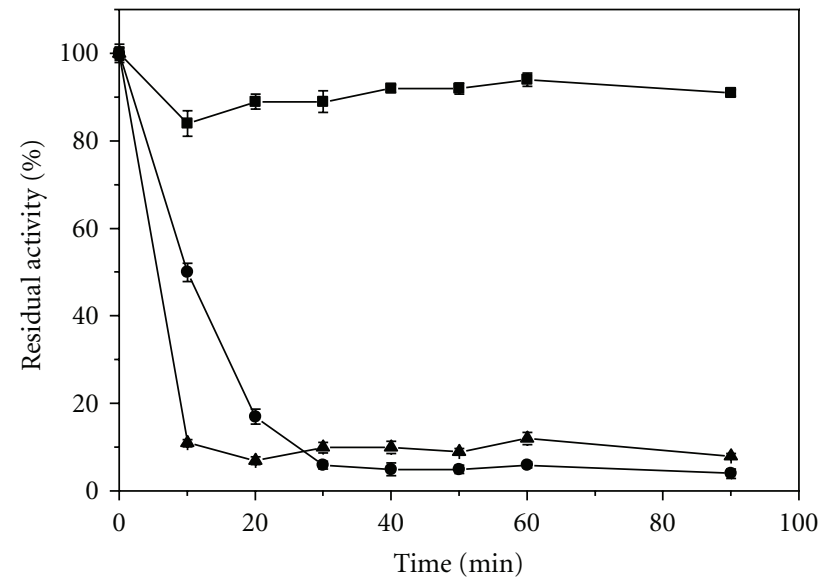

(c)

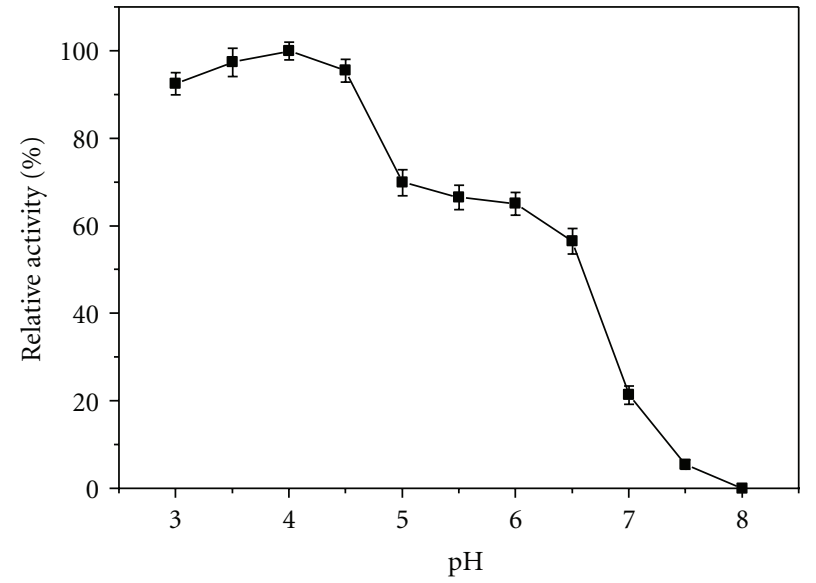

(b)

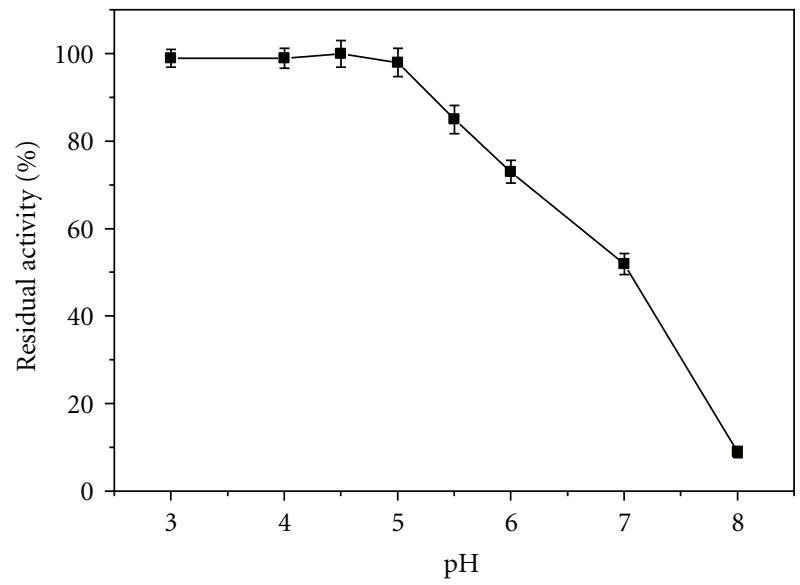

(d)

Figure 2: Biochemical characterization of the PGs produced by A. niveus. (a) Effect of the temperature; (b) pH influence, (c) thermal stability, (d) pH stability, (ם) $60^{\circ} \mathrm{C} ;(\bullet) 65^{\circ} \mathrm{C} ;(\boldsymbol{\Delta}) 70^{\circ} \mathrm{C}$. 
TABLE 2: Effect of different carbon sources on the production of PG from A. niveus under SbmF.

\begin{tabular}{|c|c|c|}
\hline Source & $\begin{array}{c}\text { Growth } \\
(\mathrm{mg} \text { total of protein })\end{array}$ & $\begin{array}{l}\text { Activity } \\
\text { (U total) }\end{array}$ \\
\hline Sigma-Aldrich Citrus Pectin & $1.9 \pm 0.07$ & $319 \pm 3$ \\
\hline None & $0.1 \pm 0.06$ & $36 \pm 3$ \\
\hline Glucose & $0.1 \pm 0.04$ & $16 \pm 2$ \\
\hline Monogalacturonic acid & $0.1 \pm 0.05$ & $102 \pm 5$ \\
\hline Polygalacturonic acid & $0.2 \pm 0.08$ & $124 \pm 4$ \\
\hline 7128 Citrus Pectin* & $2.5 \pm 0.06$ & $286 \pm 2$ \\
\hline USP-B Citrus Pectin* & $2.5 \pm 0.07$ & $274 \pm 4$ \\
\hline JMH6 Citrus Pectin* & $2.5 \pm 0.09$ & $236 \pm 4$ \\
\hline GENU 8001 Citrus Pectin* & $2.2 \pm 0.08$ & $268 \pm 3$ \\
\hline GEN 8003 Citrus Pectin* & $2.6 \pm 0.04$ & $315 \pm 3$ \\
\hline Sucrose & $3.8 \pm 0.05$ & $197 \pm 4$ \\
\hline Vetec Citrus Pectin & $1.7 \pm 0.09$ & $307 \pm 5$ \\
\hline Galactose & $3.1 \pm 0.10$ & $26 \pm 2$ \\
\hline Trehalose & $2.6 \pm 0.05$ & $67 \pm 3$ \\
\hline Raffinose & $2.7 \pm 0.04$ & $60 \pm 2$ \\
\hline Arabinose & $3.8 \pm 0.04$ & $172 \pm 4$ \\
\hline Penetrose & $5.2 \pm 0.07$ & $170 \pm 3$ \\
\hline Gum guar & $3.7 \pm 0.11$ & $244 \pm 2$ \\
\hline Apple peel (Malus domestica) & $4.5 \pm 0.09$ & $248 \pm 7$ \\
\hline Orange peel (Citrus sinensis) & $2.4 \pm 0.10$ & $335 \pm 9$ \\
\hline Lemon peel (Citrus latifolia) & $3.1 \pm 0.12$ & $300 \pm 8$ \\
\hline Passion fruit peel (Passiflora edulis) & $3.6 \pm 0.11$ & $313 \pm 6$ \\
\hline commercial mate herb (Illex paraguariensis) & $4.9 \pm 0.09$ & $136 \pm 7$ \\
\hline Rice straw (Oryza sativa) & $1.0 \pm 0.04$ & $35 \pm 4$ \\
\hline Sugar cane bagasse (Saccharum officinarum) & $1.6 \pm 0.07$ & $95 \pm 6$ \\
\hline Corn cob (Zea mays) & $1.2 \pm 0.03$ & $105 \pm 8$ \\
\hline Wheat bran (Triticum aestivum) & $3.1 \pm 0.13$ & $92 \pm 5$ \\
\hline Soya bran (Glycine max) & $3.3 \pm 0.10$ & $73 \pm 4$ \\
\hline
\end{tabular}

*FROM CPKelco Brasil S/A.

TABLE 3: Effect of different carbon sources on the production of PG from A. niveus under SSF.

\begin{tabular}{lcc}
\hline Source & $\begin{array}{c}\text { Growth } \\
\text { (mg total of protein) }\end{array}$ & $\begin{array}{c}\text { Activity } \\
\text { (U total) }\end{array}$ \\
\hline Orange peel (Citrus sinensis) & $46 \pm 2.9$ & $495 \pm 33$ \\
Lemon peel (Citrus latifolia) & $39 \pm 1.5$ & $1324 \pm 57$ \\
Passion fruit peel (Passiflora edulis) & $42 \pm 7.3$ & $960 \pm 15$ \\
Apple peel (Malus domestica) & $42 \pm 2.4$ & $311 \pm 36$ \\
Rice straw (Oryza sativa) & $5 \pm 0.1$ & $318 \pm 27$ \\
Wheat bran (Triticum aestivum) & $26 \pm 1.4$ & $407 \pm 25$ \\
Corn cob (Zea mays) & $14 \pm 0.5$ & $416 \pm 1$ \\
Sugar cane bagasse (Saccharum officinarum) & $5 \pm 0.1$ & $272 \pm 10$ \\
\hline
\end{tabular}

3.3. Biochemical Characterization of Polygalacturonase Activity. The enzyme used to biochemical characterization was the extracellular PG produced in medium supplemented with Sigma-Aldrich citrus pectin, because it showed elevated activity and few contaminants. The optima of temperature and $\mathrm{pH}$ were $55^{\circ} \mathrm{C}$ and the $\mathrm{pH}$ range of $3.0-4.5$ (Figures 2(a) and 2(b)). The enzyme retained $91 \%$ of the activity after $90 \mathrm{~min}$ at $60^{\circ} \mathrm{C}$; higher temperatures severely inactivated the enzyme (Figure 2(c)). PG activity remained stable after $24 \mathrm{~h}$ at $4-6^{\circ} \mathrm{C}$ at the $\mathrm{pH}$ range of 3.0-5.0, with a decrease of $15 \%$ at $\mathrm{pH} 5.5$ and $91 \%$ at $\mathrm{pH} 8.0$ (Figure $2(\mathrm{~d})$ ).

The effect of different salts and EDTA ( 1 and $10 \mathrm{mM}$, final concentration) on PG activity is shown in Table 4. EDTA and $\mathrm{Mn}^{2+}$ generated a slight increase in the enzymatic activity. 
TABLE 4: Effect of metal ions and EDTA on the activity of the PG produced by $A$. niveus.

\begin{tabular}{lcc}
\hline Compound & \multicolumn{2}{c}{ Relative activity $(\%)$} \\
& $1 \mathrm{mM}$ & $10 \mathrm{mM}$ \\
\hline None & $100 \pm 2.1$ & $100 \pm 1.3$ \\
$\mathrm{Hg}^{2+}$ & $59 \pm 2.9$ & $4 \pm 1.0$ \\
$\mathrm{NH}_{4}^{+}$ & $87 \pm 3.0$ & $87 \pm 2.1$ \\
$\mathrm{Ca}^{2+}$ & $97 \pm 2.8$ & $78 \pm 2.5$ \\
$\mathrm{Zn}^{2+}$ & $87 \pm 2.6$ & $75 \pm 2.2$ \\
$\mathrm{Ba}^{2+}$ & $101 \pm 1.3$ & $39 \pm 2.8$ \\
$\mathrm{Cu}^{2+}$ & $60 \pm 1.9$ & $48 \pm 2.4$ \\
$\mathrm{Na}^{+}$ & $95 \pm 2.8$ & $93 \pm 2.0$ \\
$\mathrm{Mn}^{2+}$ & $117 \pm 1.4$ & $113 \pm 3.2$ \\
$\mathrm{Mg}^{2+}$ & $72 \pm 2.9$ & $92 \pm 2.9$ \\
$\mathrm{Al}^{2+}$ & $98 \pm 2.3$ & $93 \pm 2.1$ \\
$\mathrm{EDTA}^{2+}$ & $110 \pm 3.2$ & $94 \pm 3.3$ \\
\hline
\end{tabular}

However, $10 \mathrm{mM} \mathrm{Hg}^{2+}, \mathrm{Ba}^{2+}$, and $\mathrm{Cu}^{2+}$ inhibited 96, 61, and $52 \%$ of the PG activity, respectively.

\section{Discussion}

Aspergillus niveus turned out to be a good pectinase producer in cultures grown with agro-industrial residues. It is very convenient to use such residues to produce the enzyme in industrial scale, once their use reduces costs and aggregates value to the organic material, bringing benefits to the environment as well as the industry. When grown in Czapeck medium, the fungus had maximum PG production after 5 days. Patil and Dayanand [17] and Friedrich et al. [18] described similar period of time for pectinase production by different strains of Aspergillus niger in submerged cultures. The present study demonstrated that fruit peels, especially orange peels, considerably stimulated the production of PG under SbmF. However, Niture and Pant [19] described that orange peel induced elevated levels of PG II in Fusarium moniliforme grown in semisolid medium. Besides, our results showed that PG production by A. niveus was better under SSF than under SbmF, considering the same carbon source. The PG production with rice straw was 9.1-fold higher under SSF than in SbmF, followed by lemon peel and wheat bran (4.4fold), corn cob (3.9-fold), passion fruit (3.1-fold), sugar cane bagasse (2.9-fold), orange peel (1.5-fold), and apple peel (1.3-fold). These results suggested that the high enzymatic production is due to a close contact of the microorganism with the carbon source, observed in SSF.

A. niveus is a thermotolerant fungus [20]; so, the PG secreted was quite active and stable at $60^{\circ} \mathrm{C}$. Mohamed et al. [21] described a PG with optimum activity at $40^{\circ} \mathrm{C}$. Kashyap et al. [22] and Moyo et al. [23] describe the maximum temperature of $50^{\circ} \mathrm{C}$ for the $\mathrm{PG}$ of A. niger and Kluyveromyces wickerhamii, respectively. The optimum temperature for PG from Bacillus sp. [4], Trichoderma harzianum [24], T. reesei [21], and A. niger [25] was about 40 and $50^{\circ} \mathrm{C}$.

The A. niveus $\mathrm{PG}$ was stable for $90 \mathrm{~min}$ at $60^{\circ} \mathrm{C}$. Mohamed et al. [24] describe that the PG of Trichoderma harzianum was stable for $30 \mathrm{~min}$ at $60^{\circ} \mathrm{C}$. Thus, the PG from A. niveus may be advantageous for the industrial processes of candy, syrups, juice, and drink production.

PG activity was predominantly acidic, presenting two plateaus ( $\mathrm{pH}$ range of 3-4.5 and 5-6.5, suggesting more than one enzymatic form). For A. niger [24] and Fusarium moniliforme [18], the maximum $\mathrm{PG}$ activity occurred at $\mathrm{pH}$ 5.0, and for T. reesei PGs at $\mathrm{pH} 4.5$ and 4.2 [24]. The enzyme from $A$. niveus was stable in a $\mathrm{pH}$ range of $3.0-5.0$, for $24 \mathrm{~h}$ at $4-6^{\circ} \mathrm{C}$. The $\mathrm{PG}$ from T. harzianum [24] was stable at $\mathrm{pH}$ 5.0, and PG from A. fumigatus [3] was stable in a $\mathrm{pH}$ range of 3.0-9.0. Kobayashi et al. [26] demonstrated that PG from Bacillus sp. was stable at $\mathrm{pH} 6.0$ and 12.0 at $30^{\circ} \mathrm{C}$ for $1 \mathrm{~h}$.

EDTA and $\mathrm{Mn}^{2+}$ increased the enzymatic activity of the PG from A. niveus, and $\mathrm{Hg}^{2+}, \mathrm{Ba}^{2+}$, and $\mathrm{Cu}^{2+}$ inhibited it. The effect of $\mathrm{Hg}^{2+}$ suggested the presence of $\mathrm{SH}$ groups on the protein, which was a covalent bound with this metal turning the three-dimensional structure unstable and decreasing its enzymatic activity. PGII from T. harzianum [24] was totality inhibited by $1 \mathrm{mM} \mathrm{Mn}^{2+}$ and $\mathrm{Co}^{2+}$. The activity of Sporotrichum thermophile Apinis PG was stimulated by $\mathrm{Fe}^{2+}$ and $\mathrm{Mn}^{2+}$ both at 1 and $5 \mathrm{mM}$, while $\mathrm{Ca}^{2+}$ and $\mathrm{Cu}^{2+}$ stimulated only at $1 \mathrm{mM}$ and $5 \mathrm{mM} . \mathrm{Mg}^{2+}$ strongly inhibited enzyme activity [27]. The PG of Bacillus MG-cp-2 was stimulated by $\mathrm{Ca}^{2+}[4]$.

In conclusion, agro-industrial residues, such as orange and lemon peel, induce high levels of a thermostable acid PG by $A$. niveus. Finally, the use of these residues on industrial enzymatic production would aggregate value to waste and would reduce the environmental pollution.

\section{Acknowledgments}

This work was supported by grants from Fundação de Amparo à Pesquisa do Estado de São Paulo (FAPESP) and Conselho de Desenvolvimento Científico e Tecnológico (CNPq). João Atîlio Jorge and Maria de Lourdes Teixeira de Moraes Polizeli are Research Fellows of CNPq. Alexandre Maller; André Ricardo Lima Damásio; Tony Marcio da Silva were recipients of FAPESP Fellowship. The authors thank Ricardo Alarcon, Mariana Cereia and Mauricio de Oliveira for technical assistance.

\section{References}

[1] S. Yadav, P. K. Yadav, D. Yadav, and K. D. S. Yadav, "Purification and characterization of pectin lyase produced by Aspergillus terricola and its application in retting of natural fibers," Applied Biochemistry and Biotechnology, vol. 159, no. 1, pp. 270-283, 2009.

[2] A. N. Round, N. M. Rigby, A. J. MacDougall, and V. J. Morris, "A new view of pectin structure revealed by acid hydrolysis and atomic force microscopy," Carbohydrate Research, vol. 345, no. 4, pp. 487-497, 2010.

[3] G. Hoondal, R. Tiwari, R. Tewari, N. Dahiya, and Q. Beg, "Microbial alkaline pectinases and their industrial applications: a review," Applied Microbiology and Biotechnology, vol. 59, no. 4-5, pp. 409-418, 2002. 
[4] M. Kapoor, Q. Khalil Beg, B. Bhushan, K. S. Dadhich, and G. S. Hoondal, "Production and partial purification and characterization of a thermo-alkali stable polygalacturonase from Bacillus sp. MG-cp-2," Process Biochemistry, vol. 36, no. 5, pp. 467-473, 2000.

[5] J. H. A. Betini, M. Michelin, S. C. Peixoto-Nogueira, J. A. Jorge, H. F. Terenzi, and M. L. T. M. Polizeli, "Xylanases from Aspergillus niger, Aspergillus niveus and Aspergillus ochraceus produced under solid-state fermentation and their application in cellulose pulp bleaching," Bioprocess and Biosystems Engineering, vol. 32, no. 6, pp. 819-824, 2009.

[6] S. C. Peixoto-Nogueira, M. Michelin, J. H. A. Betini, J. A. Jorge, H. F. Terenzi, and M. L. T. M. Polizeli, "Production of xylanase by Aspergilli using alternative carbon sources: application of the crude extract on cellulose pulp biobleaching," Journal of Industrial Microbiology and Biotechnology, vol. 36, no. 1, pp. 149-155, 2009.

[7] T. M. Silva, M. Michelin, A. R. L. Damásio et al., "Purification and biochemical characterization of a novel $\alpha$-glucosidase from Aspergillus niveus," Antonie van Leeuwenhoek, vol. 96, no. 4, pp. 569-578, 2009.

[8] T. M. Silva, A. Maller, A. R. L. De Lima Damásio et al., "Properties of a purified thermostable glucoamylase from Aspergillus niveus," Journal of Industrial Microbiology and Biotechnology, vol. 36, no. 12, pp. 1439-1446, 2009.

[9] A. Wiseman, Handbook of Enzyme Biotechnology, John Wiley \& Sons, 1975.

[10] R. M. Peralta, H. F. Terenzi, and J. A. Jorge, “ $\beta$-D-glycosidase activities of Humicola grisea: biochemical and kinetic characterization of a multifunctional enzyme," Biochimica et Biophysica Acta, vol. 1033, no. 3, pp. 243-249, 1990.

[11] P. R. Adams, "Mycelial amylase activities of thermophilic species of Rhizomucor, Humicola and Papulaspora," Mycopathologia, vol. 112, no. 1, pp. 35-37, 1990.

[12] P. Khanna, S. Sivakami Sundari, and N. J. Kumar, "Production, isolation and partial purification of xylanases from an Aspergillus sp," World Journal of Microbiology and Biotechnology, vol. 11, no. 2, pp. 242-243, 1995.

[13] A. C. S. Rizzatti, J. A. Jorge, H. F. Terenzi, C. G. V. Rechia, and M. L. T. M. Polizeli, "Purification and properties of a thermostable extracellular $\beta$-D-xylosidase produced by a thermotolerant Aspergillus phoenicis," Journal of Industrial Microbiology and Biotechnology, vol. 26, no. 3, pp. 156-160, 2001.

[14] G. L. Miller, "Use of dinitrosalicylic acid reagent for determination of reducing sugar," Analytical Chemistry, vol. 31, no. 3, pp. 426-428, 1959.

[15] O. H. Lowry, N. J. Rosebrough, A. L. Farr, and R. J. Randal, "Protein measurement with the Folin phenol reagent," The Journal of Biological Chemistry, vol. 193, no. 1, pp. 265-275, 1951.

[16] M. Cereia, H. F. Terenzi, J. A. Jorge, L. J. Greene, J. C. Rosa, and M. L. T. M. Polizeli, "Glucoamylase activity from the thermophilic fungus Scytalidium thermophilum. Biochemical and regulatory properties," Journal of Basic Microbiology, vol. 40, no. 2, pp. 83-92, 2000.

[17] S. R. Patil and A. Dayanand, "Production of pectinase from deseeded sunflower head by Aspergillus niger in submerged and solid-state conditions," Bioresource Technology, vol. 97, no. 16, pp. 2054-2058, 2006.

[18] J. Friedrich, A. Cinierman, and W. Steiner, "Concomitant biosynthesis of Aspergillus niger pectolytic enzymes and citric acid on sucrose," Enzyme and Microbial Technology, vol. 16, no. 8, pp. 703-707, 1994.
[19] S. K. Niture and A. Pant, "Purification and biochemical characterization of polygalacturonase II produced in semi-solid medium by a strain of Fusarium moniliforme," Microbiological Research, vol. 159, no. 3, pp. 305-314, 2004.

[20] S. J. Taj-Aldeen and K. I. Alkenany, "Separation and partial purification of beta-glucosidase and two endoglucanases in Aspergillus niveus," Microbiologia, vol. 12, no. 1, pp. 91-98, 1996.

[21] S. A. Mohamed, T. M. I. E. Christensen, and J. D. Mikkelsen, "New polygalacturonases from Trichoderma reesei: characterization and their specificities to partially methylated and acetylated pectins," Carbohydrate Research, vol. 338, no. 6, pp. 515-524, 2003.

[22] D. R. Kashyap, P. K. Vohra, S. Chopra, and R. Tewari, "Applications of pectinases in the commercial sector: a review," Bioresource Technology, vol. 77, no. 3, pp. 215-227, 2001.

[23] S. Moyo, B. A. Gashe, E. K. Collison, and S. Mpuchane, "Optimising growth conditions for the pectinolytic activity of Kluyveromyces wickerhamii by using response surface methodology," International Journal of Food Microbiology, vol. 85, no. 1-2, pp. 87-100, 2003.

[24] S. A. Mohamed, N. M. Farid, E. N. Hossiny, and R. I. Bassuiny, "Biochemical characterization of an extracellular polygalacturonase from Trichoderma harzianum," Journal of Biotechnology, vol. 127, no. 1, pp. 54-64, 2006.

[25] M. V. Nikolić and L. Mojovic, "Hydrolysis of apple pectin by the coordinated activity of pectic enzymes," Food Chemistry, vol. 101, no. 1, pp. 1-9, 2007.

[26] T. Kobayashi, N. Higaki, A. Suzumatsu et al., "Purification and properties of a high-molecular-weight, alkaline exopolygalacturonase from a strain of Bacillus," Enzyme and Microbial Technology, vol. 29, no. 1, pp. 70-75, 2001.

[27] G. Kaur, S. Kumar, and T. Satyanarayana, "Production, characterization and application of a thermostable polygalacturonase of a thermophilic mould Sporotrichum thermophile Apinis," Bioresource Technology, vol. 94, no. 3, pp. 239-243, 2004. 

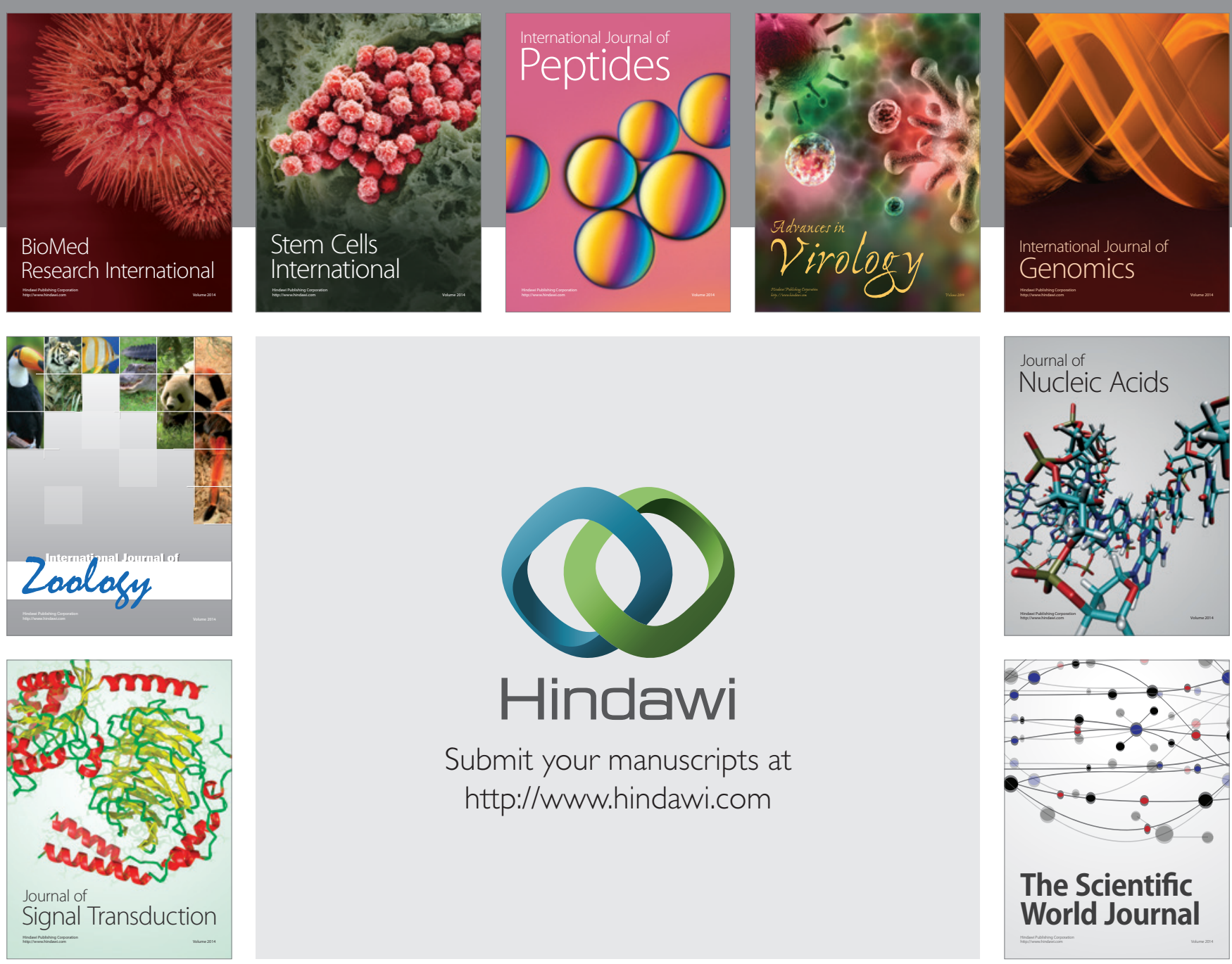

Submit your manuscripts at

http://www.hindawi.com
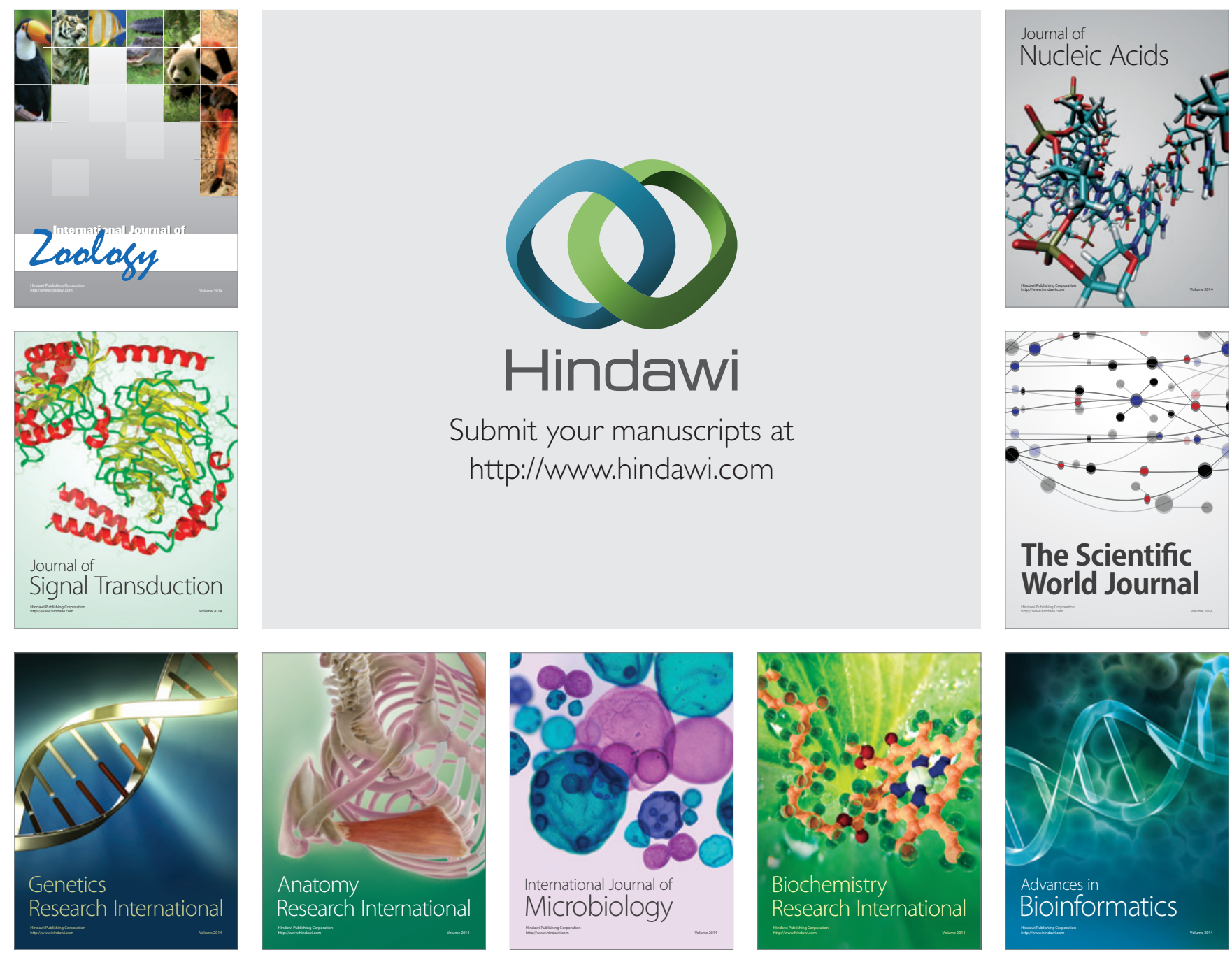

The Scientific World Journal
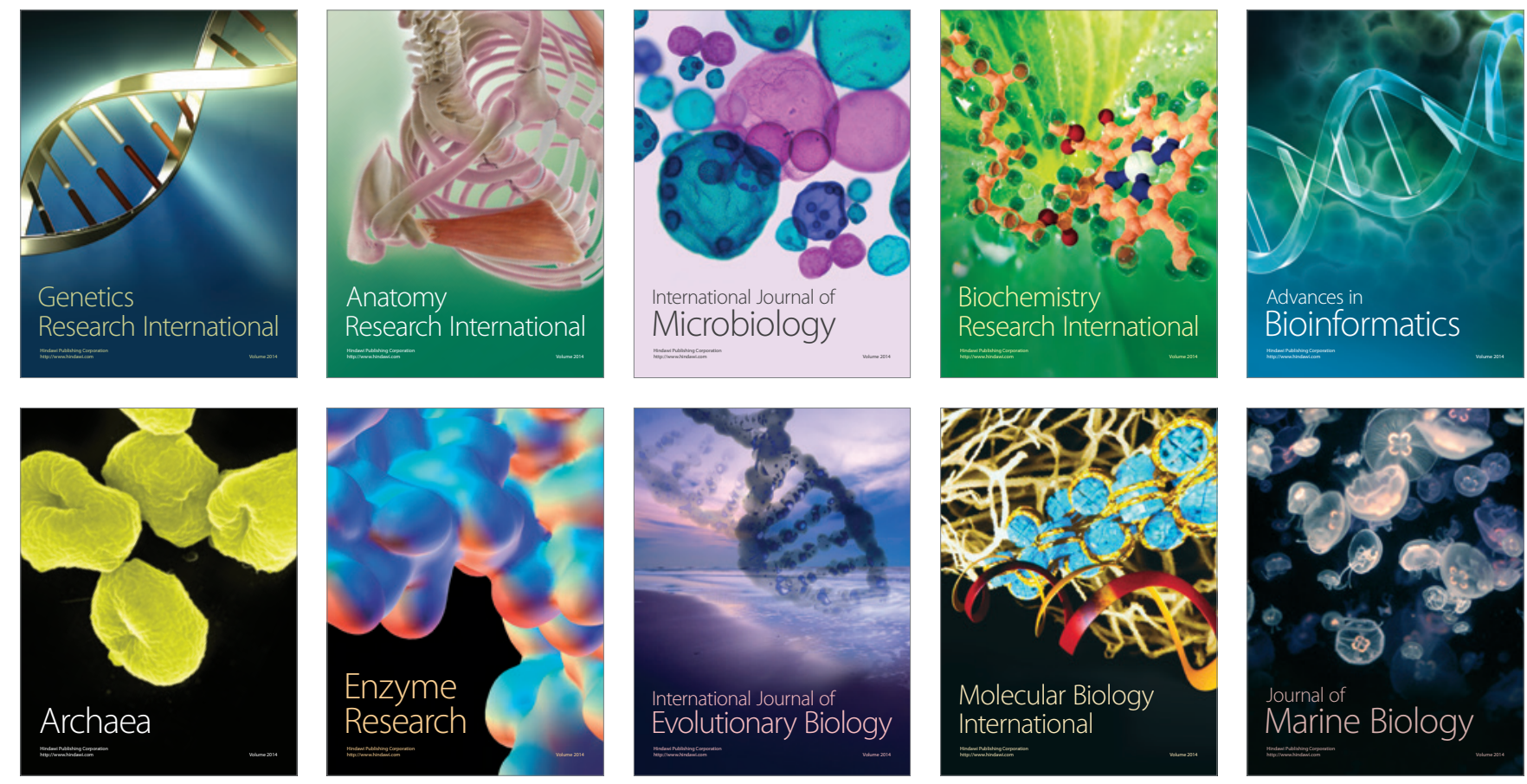